\title{
STRUKTUR KOMUNITAS PLANKTON DI DANAU TAMBLINGAN KABUPATEN BULELENG BALI
}

\section{PLANKTON COMMUNITY STRUCTURE IN TAMBLINGAN LAKE, BULELENG DISTRICT, BALI}

\author{
Fendria Wadi, Deny Suhernawan Yusuf, Ni Made Suartini \\ Program Studi Biologi, Fakultas Matematika dan Ilmu Pengetahuan Alam, Universitas Udayana, Kampus Bikit \\ Jimbaran, Badung-Bali(80631) \\ Email:fendriawadi0@gmail.com
}

\begin{abstract}
ABSTRAK
Penelitian dilakukan bertujuan untuk mengetahui struktur komunitas plankton Danau Tamblingan dan aktivitas komunitas di daerah sekitar danau dan di badan danau. Ada dua metode yang digunakan dalam penelitian ini. Metode pertama adalah metode survei yaitu pengamatan langsung lokasi berdasarkan pemanfaatan kawasan danau. Metode kedua adalah metode deskriptif kuantitatif dengan menggambarkan fenomena berdasarkan perhitungan indeks ekologi. Hasil penelitian memperoleh komposisi plankton terdiri atas lima filum yang mana filum Chlorophyta mendominasi. Genus yang sering ditemukan serta kelimpahannya tinggi adalah Cosmarium, Staurastum, dan Nitzshia. Kelimpahan plankton adalah 5,757 11,197 sel/liter dengan nilai indeks keanekaragaman ( $\left.\mathrm{H}^{\prime}\right)$ 1,38 - 1,76 yang mana tergolong kategori sedang, indeks keseragaman (E) 0,52-0,65 tergolong kategori sedang, indeks dominansi (C) 0,35-0,48 yang menunjukkan tidak terdapat dominasi genus tertentu. Sebagian besar masyarakat pada kawasan danau Tamblingan adalah sebagai petani dan nelayan. Aktivitas masyarakat yang berpengaruh terhadap danau sangat rendah sehingga tidak berdampak terhadap perairan Danau Tamblingan.
\end{abstract}

Kata kunci: aktivitas masyarakat, perubahan kondisi danau, plankton

\section{ABSTRACT}

The research was conducted to determine the structure of the plankton community of Lake Tamblingan and community activities in the area around the lake and in the lake body. There are two methods used in this research. The first method is a survey method, namely direct observation of the location based on the utilization of the lake area. The second method is a quantitative descriptive method by describing the phenomenon based on the calculation of the ecological index. The results showed that the composition of plankton consists of five phyla in which the phylum Chlorophyta dominates. The genera that are often found with high abundance are Cosmarium, Staurastum, and Nitzshia. The abundance of plankton was 5,757 - 11,197 cells/liter with a diversity index value $\left(\mathrm{H}^{\prime}\right)$ of 1,38 - 1,76 which was classified as moderate category, uniformity index (E) 0,52-0,65 was classified as moderate category, dominance index (C) ) 0.35-0.48 which indicates that there was no dominance of a particular genus. Most of the people in the Tamblingan lake area are farmers and fishermen. Community activities that affect the lake are so low that they have no impact on the waters of Lake Tamblingan.

Keyword: community activities, changes in lake conditions, plankton

\section{PENDAHULUAN}

Danau Tamblingan yang berada di kecamatan Banjar, termasuk dalam kawasan Taman Wisata Alam (TWA) Danau Buyan - Danau Tamblingan yang berada dalam pengawasan BKSDA Bali, 
yang mana terletak pada $8^{\circ} 14^{\prime} 8^{\prime \prime} L S$ dan $115^{\circ} 05^{\prime} 15^{\prime \prime}$ 'BT dengan luas kawasan adalah 1,703 ha (Sutomo, 2014). Danau Tamblingan berfungsi sebagai kawasan lindung dengan tujuan melindungi sumber daya alam dan sumber daya buatan karena merupakan daerah tangkapan air (PERDA Prov Bali No 16, 2016).

Berdasarkan data jumlah penduduk Kabupaten Buleleng (2019), jumlah penduduk di Kecamatan Banjar dari tahun 2000-2018 terus mengalami peningkatan. Laju pertambahan penduduk menyebabkan bergesernya alih fungsi lahan di kawasan Danau Tamblingan, diantaranya yaitu untuk lahan pertanian dan perkebunan. Kabupaten Buleleng mengalami peningkatan lahan 1 hektar per tahunnya dari tahun 2011 hingga 2015 (Wibowo 2017). Adanya alih fungsi lahan ini diduga dapat mengakibatkan masuknya bahan pencemar secara berlebih ke badan perairan danau Tamblingan yang seiring waktu akan memicu terjadinya penurunan kualitas perairan. Bahan pencemar tersebut dapat berupa residu dari penggunaan pupuk anorganik dan pestisida. Menurut Manuaba (2009), dengan meningkatnya jumlah lahan pertanian dan perkebunan maka penggunaan pupuk dan pestisida juga meningkat.

Air danau termasuk juga air Danau Tamblingan memiliki berbagai macam fungsi sehingga perannya penting dalam kehidupan. Fungsinya diantaranya adalah untuk aktifitas pertanian, peternakan, dan penangkapan ikan. Dengan demikian tidak jarang kualitas air danau akan terpengaruh oleh aktifitas tersebut. Salah satu bioindikator untuk mengetahui kualitas suatu perairan danau adalah keberadaan plankton khususnya fitoplankton (Munthe dkk., 2012). Menurut Fukuyo and Borja
(2000) beberapa plankton yang termasuk dalam indikator pencemaran perairan adalah Phormodium, Pyrobotrys, Oscillatoria, Chlorella, Anacystis, Nitzschia,. Lepocinclis, Tetraedron, Phacus, Stigeoclonium, Chlamydomonas, Agemenellum, Anabaena, Euglena, Spyrogyra, Chlorococcum, Ghomponema, Lyngbya, Carteria, Chlorogonium, dan Arthrospira.

Masukan nutrient seperti nitrat dan fosfat (unsur hara makro plankton) yang merupakan residu dari aktivitas pertanian akan mempengaruhi kepadatan plankton (Risamasu dan Prayitno, 2011). Peningkatan jumlah plankton tertentu dapat dijadikan sebagai indikasi tingginya nutrient pada perairan tersebut, dimana nutrient yang tinggi akan berdampak pada penurunan kualitas perairan terlebih jika kadarnya melebihi ambang batas yang ditetapkan.

Berdasarkan latar belakang di atas maka penting untuk dilakukan penelitian terkait struktur komunitas plankton sebagai bioindikator kualitas perairan. Dan juga perlu dilakukan survey terhadap aktivitas masyarakat pada kawasan danau Tamblingan sebagai data pendukung.

\section{METODE PENELITIAN}

\section{Waktu dan Tempat Penelitian}

Sampel plankton diambil di Danau Tamblingan, Desa Munduk, Kecamatan Banjar, Kabupaten Buleleng pada tanggal 3 Januari 2019, 7 Februari 2019, dan 25 Februari 2019. Pengambilan sampel dilakukan di tiga stasiun yang mewakili kawasan danau diantaranya: Stasiun I (kawasan pertanian), Stasiun II (kawasan peralihan) dan Stasiun III (kawasan hutan). Stasiun pengambilan sampel tersaji pada Gambar 1. 


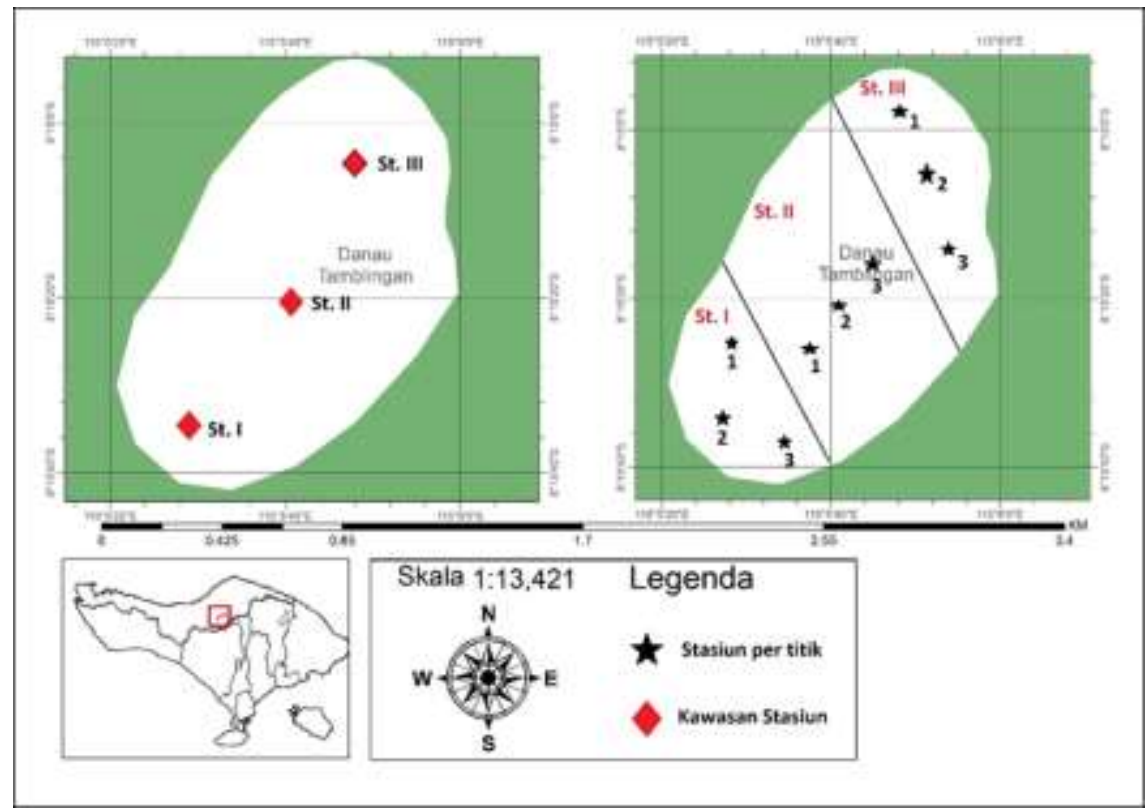

Gambar 1. Stasiun penelitian di Danau Tamblingan

\section{Metode Pengumpulan Data}

Pengambilan sampel plankton dilakukan pada siang hari (dari jam 11.00 13.00 WITA). Pada masing-masing stasiun diambil tiga titik sebanyak tiga kali ulangan. Pada masing-masing titik sampling, air di bagian permukaan diambil menggunakan ember plastik dengan volume 5 liter sebanyak 30 kali (total 150 liter (Vs) dan dituangkan kedalam plankton net no. 25 yang pada ujungnya telah diikatkan dengan botol penampung sampel $17 \mathrm{ml}$ (Vr). Sampel yang sudah terkumpul dalam botol penampung sampel dipindahkan ke botol balsem volume 20 ml, lalu ditetesi 2 tetes Lugol $10 \%$ dan 2 tetes formalin $4 \%$. Sampel dimasukkan kedalam coolbox berisi es batu dan dibawa ke Laboratorium Ekologi Program Studi Biologi Fakultas Matematika dan Ilmu Pengetahuan Alam, Universitas Udayana untuk diidentifikasi mengacu pada pustaka Plankton of Vietnam oleh Shirota (1966) dan A Beginner's Guide to Freshwater Algae (Belcher and Swale, 1978).

Sampel plankton diamati di bawah mikroskop yang memiliki luas lapang pandang 0,04 $\mathrm{mm}$ (Op) dengan menggunakan gelas objek, ditetesi sampel plankton sebanyak 2 tetes yang setara dengan 0,09 $\mathrm{ml}$ (Vo), kemudian ditutup dengan coverglass berukuran 18 x 18 $\mathrm{mm}^{2}$ (Oi). Tiap botol sampel diulang sebanyak tiga kali. Pengamatan sampel plankton dilakukan dengan membagi jumlah lapang pandang menjadi 25 lapang pandang $(\mathrm{P})$.

Variabel yang diamatai adalah jenis jenis plankton dan jumlah sel tiap takson plankton. Kepadatan sel tiap jenis takson dihitung dengan menggunakan rumus dari Sachlan (1982).

$$
\mathrm{N}=\mathrm{n} \times \frac{O \mathrm{i}}{O p} \times \frac{V r}{V o} \times \frac{1}{V s} \times \frac{1}{P}
$$

Keterangan:

$\mathrm{N}=$ jumlah total sel plankton (sel/L)

$\mathrm{n} \quad=$ jumlah rata rata sel plankton yang dicacah pada seluruh lapang pandang 


$$
\begin{aligned}
& \text { Oi }=\text { luas cover glass }\left(\mathrm{mm}^{2}\right) \\
& \mathrm{Op}=\text { luas lapang pandang }\left(\mathrm{mm}^{2}\right) \\
& \mathrm{Vr}=\text { volume air tersaring }(\mathrm{mL}) \\
& \mathrm{Vo}=\text { volume air yang diamati }(\mathrm{mL}) \\
& \mathrm{Vs}=\text { volume air yang disaring }(\mathrm{L}) \\
& \mathrm{P} \quad=\text { jumlah lapang pandang }=25
\end{aligned}
$$

\section{Analisis data}

Data plankton yang didapatkan dianalisis dengan menghitung indeks keanekaragaman, keseragaman dan dominansi.

Indeks keanekaragaman plankton dihitung dengan mengunakan rumus dari Shannon- Wiener (1949):

$\mathrm{H}^{\circ}=-\Sigma\left(\frac{\mathrm{ni}}{\mathrm{N}}\right) \operatorname{In}\left(\frac{\mathrm{ni}}{\mathrm{N}}\right)$

Keterangan:

$\mathrm{H}^{\prime}=$ indeks keanekaragaman ShannonWiener

$\mathrm{ni}=$ jumlah individu taxon ke- $\mathrm{i}$

$\mathrm{N}=$ jumlah total individu seluruh taxon

Nilai $\mathrm{H}^{\prime}<1$ menandakan keanekaragaman rendah, kestabilan komunitas rendah dan tekanan ekologis berat. Nilai $1,0<\mathrm{H}^{\prime}<$ 3,322 maka keanekaragaman sedang, kondisi ekosistem sedang, dan tekanan ekologis sedang. Nilai H'> 3,322 maka keanekaragaman tinggi, stabilitas ekosistem tinggi, tekanan ekologis rendah.

Indeks keseragaman dihitung dengan menggunakan rumus dari Shannon- Wiener (1949) sebagai berikut:

$\mathrm{E}=\frac{\mathrm{H}^{p}}{\mathrm{H} \max }$

Keterangan:

$\mathrm{E} \quad=$ indeks keseragaman

$\mathrm{H} \max =\ln \mathrm{S}(\mathrm{S}=$ jumlah takson $)$

Menurut Krebs (1989), bila nilai E mendekati 0 maka nilai keseragaman semakin rendah dalam suatu populasi dan jika nilai $\mathrm{E}$ mendekati 1 maka menunjukkan keseragaman yang artinya komunitas tersebut memiliki jenis yang relatif sama. Nilai indeks keseragaman menurut Supono (2008) berkisar antara 0-1 dengan syarat jika nilai $\mathrm{E}>0,6$ maka keseragaman jenis tergolong tinggi, jika $0,6 \geq \mathrm{E} \geq 0,4$ maka keseragaman jenis tergolong sedang dan jika $\mathrm{E}<0,4$ maka keseragaman jenis rendah.

Indeks dominansi dihitung dengan menggunakan rumus Simpson (Basmi, 2000) sebagai berikut:

$\mathrm{C}=1-\mathrm{E}$

Keterangan:

$\mathrm{C}=$ indeks dominansi

$\mathrm{E}=$ indeks keseragaman

Berdasarkan perhitungan indeks dominansi simpson berlaku ketentuan $0<\mathrm{C} \leq 0,5$ maka tidak ada spesies yang mendominasi dan jika $0,5<\mathrm{C}<1$ maka terdapat genus yang mendominasi.

\section{Pengukuran faktor fisika kimia air danau}

Faktor fisika-kimia lingkungan diukur secara langsung (insitu) dan tidak langsung (eksitu) di laboratorium. Pengukuran fisika-kimia lingkungan yang diukur secara langsung adalah kecerahan air, suhu air, $\mathrm{pH}$. Sedangkan pengukuran yang dilakukan di laboratorium adalah NO3 (Nitrat) dan PO4 (fosfat). Baku mutu yang menjadi acuan adalah Peraturan Pemerinta 82 Tahun 2001 Kelas II, dimana yang peruntukkannya adalah 
prasarana/sarana rekreasi air, pembudidayaan ikan air tawar, peternakan, dan pertanian.

\section{HASIL DAN PEMBAHASAN}

Faktor fsika kimia air Danau

Tamblingan

Berdasarkan hasil pengukuran faktor fisika air, tingkat kecerahan air Danau Tamblingan berkisar 240-262 cm. Nilai kecerahan paling tinggi adalah pada stasiun III, sedangkan nilai pling rendah adalah stasiun I. Nilai suhu air Danau Tamblingan tertinggi adalah $25^{\circ} \mathrm{C}$ pada stasiun I, II, sedangkan terendah adalah $24^{\circ} \mathrm{C}$ III. Nilai derajat keasaman air $(\mathrm{pH})$ adalah 7 di semua stasiun. Kadar Nitrat Danau Tamblingan berkisar 0,102-0,206 $\mathrm{mg} / \mathrm{l}$, nilai paling tinggi ada di II dan paling rendah di stasiun III. Sedangkan kadar fosfat Danau Tamblingan berkisar 0,104-0,244 mg/l, nilai paling tinggi ada di stasiun II dan paling endah di stasiun I. Faktor fisika kimia air terukur disajikan pada Tabel 1.

\section{Struktur komunitas plankton}

Genus dengan kelimpahan tinggi yaitu Cosmarium, Nitzschia, dan Staurastum. Nilai kepadatan paling tinggi yaitu di stasiun II sedangkan paling rendah terendah ad di stasiun I. Indeks keanekaragaman paling tinggi adalah di stasiun I dan paling rendah di stasiun II. Indeks keseragaman paling tinggi adalah di stasiun I dan paling rendah di stasiun II. Indeks dominansi paling tinggi ada di stasiun II dan paling rendah di stasiun I. Pada Tabel 2 tersaji nilai indeks dan keanekaragaman plankton Danau Tamblingan.

Tabel 1. Hasil pengukuran faktor fisika kimia air Danau Tamblingan

\begin{tabular}{lcccccc}
\hline \multirow{2}{*}{ Parameter } & \multirow{2}{*}{ Satuan } & \multicolumn{3}{c}{ Stasiun } & \multirow{2}{*}{ Danau } & $\begin{array}{c}\text { Baku mutu kelas II } \\
\text { PP No.82 Thn 2001 }\end{array}$ \\
\cline { 3 - 5 } Fisika & & I & II & III & & - \\
$\quad$ Kecerahan air & $\mathrm{cm}$ & 240 & 257 & 262 & 253 & $6-9$ \\
pH & - & 7 & 7 & 7 & 7 & Deviasi 3 \\
$\quad \begin{array}{l}\text { Suhu air } \\
\text { Kimia }\end{array}$ & ${ }^{\circ} \mathrm{C}$ & 25 & 25 & 24 & 25 & 10 \\
$\quad$ Nitrat & $\mathrm{mg} / \mathrm{l}$ & 0,165 & 0,206 & 0,102 & 0,158 & 0,2 \\
$\quad$ Fosfat & $\mathrm{mg} / 1$ & 0,104 & 0,244 & 0,230 & 0,193 & \\
\hline
\end{tabular}

Tabel 2. Nilai indeks dan keanekaragaman plankton Danau Tamblingan

\begin{tabular}{|c|c|c|c|}
\hline \multirow{2}{*}{ Taxon } & \multicolumn{2}{|c|}{ Jumlah (sel/Liter) } & Rata-rata \\
\hline & Stasiun 2 & Stasiun 3 & (sel/Liter) \\
\hline
\end{tabular}

\begin{tabular}{ccccc}
\hline Chrysophyta & & & & \\
Achantes & 0 & 0 & 23 & 8 \\
Navicula & 83 & 91 & 45 & 73 \\
Nitzschia & 892 & 2.184 & 3.755 & 2.277 \\
Surirella & 0 & 23 & 23 & 15 \\
Synedra & 91 & 68 & 83 & 81 \\
Chlorophyta & & & & \\
Chlorococcum & 212 & 159 & 370 & 247 \\
Cruciginea & 113 & 0 & 113 & 76 \\
Closterium & 8 & 23 & 0 & 10
\end{tabular}




\begin{tabular}{|c|c|c|c|c|}
\hline Cosmarium & 2.063 & 3.680 & 2.773 & 2.838 \\
\hline Desmidium & 23 & 68 & 30 & 40 \\
\hline Oocystis & 8 & 0 & 23 & 10 \\
\hline Scenedesmus & 151 & 317 & 400 & 290 \\
\hline Staurastum & 1.602 & 4.020 & 2.735 & 2.785 \\
\hline Spirogyra & 8 & 0 & 0 & 3 \\
\hline Xanthidium & 0 & 68 & 23 & 30 \\
\hline Zygnemopsis & 0 & 23 & 0 & 8 \\
\hline Dictyosphaerium & 0 & 30 & 151 & 60 \\
\hline Palmella & 8 & 0 & 8 & 5 \\
\hline $\begin{array}{l}\text { Sphaerocystis } \\
\text { anophyta }\end{array}$ & 23 & 0 & 0 & 8 \\
\hline Anabaena & 0 & 23 & 0 & 8 \\
\hline Chrococcus & 23 & 91 & 98 & 71 \\
\hline \multicolumn{5}{|l|}{ otozoa } \\
\hline Peridinium & 60 & 30 & 91 & 60 \\
\hline Euglena & 23 & 0 & 0 & 8 \\
\hline Arcella & 8 & 0 & 0 & 3 \\
\hline Euglypha & 249 & 0 & 257 & 169 \\
\hline \multicolumn{5}{|l|}{ thropoda } \\
\hline Cyclops & 91 & 249 & 189 & 176 \\
\hline Daphnia & 23 & 53 & 0 & 25 \\
\hline nlah & 5.757 & 11.197 & 11.190 & 9.381 \\
\hline leks keanekaragaman (H') & 1,76 & 1,38 & 1,44 & 1,56 \\
\hline leks keseragaman $(\mathrm{E})$ & 0,65 & 0,52 & 0,54 & 0,51 \\
\hline leks dominansi (C) & 0,35 & 0,48 & 0,46 & 0,49 \\
\hline
\end{tabular}

\section{Aktivitas Masyarakat}

Data hasil wawancara berdasarkan adanya aktivitas di badan danau dan di sekitar danau yang dilakukan masyarakat di sekitar kawasan Danau Tamblingan tersaji pada Tabel 3 dan 4 .

Tabel 3. Wawancara terhadap petani

\begin{tabular}{cc}
\hline Persentase petani yang menggunakan pupuk dan pestisida & Intensitas pemupukan \\
\hline Organik $60 \%$ & $1-3 \mathrm{kali} / \mathrm{tahun}$ \\
Anorganik $40 \%$ & $1-3 \mathrm{kali} / \mathrm{tahun}$ \\
Pestisida $25 \%$ & $1-24 \mathrm{kali} / \mathrm{tahun}$ \\
\hline
\end{tabular}

Tabel 4. Wawancara terhadap nelayan

\begin{tabular}{ccc}
\hline Persentasi penggunaan alat & Persentase jenis ikan yang diperoleh & Peruntukan \\
\hline Jaring 50\% & Mujair 50\% & Jual \\
Pancing 50\% & Karper $12,50 \%$ & \\
& Lele $18,75 \%$ & Konsumsi \\
& zebra $18,75 \%$ & \\
\hline
\end{tabular}




\section{PEMBAHASAN}

\section{Faktor fisika kimia air Danau Tamblingan}

Rata-rata kecerahan (Tabel 1) paling tinggi ada di stasiun II $(257 \mathrm{~cm})$ dan III $(262 \mathrm{~cm})$. Kecerahan yang tinggi di penetrasi cahaya yang dapat masuk lebih dalam ke perairan yang disebabkan oleh letak kedua stasiun adalah di daerah terbuka. Disamping hal tersebut karena kedua stasiun ini berada agak jauh dari aktivitas mesyarakat sehingga masukan pertikel terlarut cenderung lebih sedikit. Menurut Barus (2004) kandungan lumpur, jumlah plankton, serta kandungan partikel terlarut dapat mempengaruhi kecerahan perairan. Rata-rata nilai kecerahan terendah berada pada stasiun I $(240 \mathrm{~cm})$ yang dekat dengan kawasan pertanian, dimana daerah resapan air pada kawasan ini berkurang sehingga material terlarut banyak masuk ke danau bersama air tanah apalagi ketika terjadi hujan. Nilai kecerahan Danau Tamblingan menandakan nilai optimal bagi perkembangan plankton, terutama fitoplankton, hal tersebut selaras dengan kep. MENLH (2004) yang menyebutkan bahwa kecerahan 2 - 3 meter adalah kecerahan yang sesuai dengan organisme air. Menurut Soliha dkk, (2008), makin dalam penetrasi cahaya matahari masuk ke perairan danau maka cahaya yang dapat dimanfaatkan untuk proses fotosintesis makin banyak juga dan hal tersebut berpengaruh terhadap jumlah plankton.

Nilai $\mathrm{pH}$ dari ketiga stasiun adalah 7 yang artinya derajat keasaman danau Tamblingan dalam keadaan netral. Nilai tersebut menunjukkan bahwa $\mathrm{pH}$ danau Tamblingan mendukung pertumbuhan plankton. Mengacu pada Peraturan Pemerintah Nomor 82 tahun 2001, nilai pH Danau Tamblingan memenuhi standar baku mutu yang ditetapkan yaitu 6-9 dan sesuai dengan kriteria air kelas dua yaitu salah satu peruntukannya adalah untuk perikanan. Menurut Effendi (2003) bahwa kisaran alami pH perairan tawar yaitu 7-8. Ananda dkk., (2019) menyatakan bahwa perairan dengan kondisi sangat asam atau basa akan membahayakan kelangsungan organisme air (plankton).

$\begin{array}{rrr} & \text { Kisaran suhu Danau Tamblingan } \\ \text { adalah } & 24-25^{\circ} \mathrm{C} \text {. Pada Peraturan }\end{array}$
Pemerintah Nomor 82 tahun 2001 disebutkan bahwa ambang batas suhu air yaitu deviasi 3 yang artinya jika suhu air normal $25^{\circ} \mathrm{C}$, maka kriteria air yang tergolong kelas II adalah kisaran $22-28^{\circ} \mathrm{C}$. Dengan demikian berarti suhu air Danau Tamblingan masih dapat menunjang kehidupan perairan. Menurut Effendi (2003), Pertumbuhan plankton khususnya fitoplankton baik pada perairan dengan kisaran suhu optimum $20-30^{\circ} \mathrm{C}$ (Effendi, 2003). Dengan demikian suhu air Danau Tamblingan masih baik untuk menunjang kehidupan di perairan tersebut.

\section{Struktur komunitas plankton}

Hasil identifikasi plankton di Danau Tamblingan (Tabel 2) adalah ditemukan lima filum yaitu Chrysophyta, Chlorophyta, Cyanophyta, Protozoa dan Arthropoda. Lima filum tersebut ditemukan dengan jumlah genus yang bervariasi pada masing-masing stasiun yaitu: Chrysophyta (5 genus), Chlorophyta (14 genus), Cyanophyta (2 genus), Protozoa (4 genus), Arthropoda (2 genus). Filum yang ditemukan paling banyak adalah filum Chlorophyta. Sebagian besar plankton yang termasuk Chlorophyta mempunyai klorofil a dan b yang digunakan untuk fotosintesis, sehingga memiliki laju metabolisme yang cepat (Fauziah dan Laily, 2015). Filum tersebut ditemukan lebih banyak dibandingkan 
filum lainnya diduga karena sifatnya yang kosmopolit dan mempunyai toleransi yang tinggi. Hal tersebut disebutkan dalam Sartika dkk, (2012) yang menyatakan bahwa filum Chlorophyta merupakan filum yang bersifat kosmopolit pada perairan danau, kolam, genangan air hujan dan sungai. Pratiwi dkk. (2007) menyebutkan bahwa filum itu mempunyai batas toleransi yang tinggi terhadap suhu. Menurut effendi (2003), Filum Chlorophyta mampu tumbuh dengan baik pada suhu $20-30{ }^{\circ} \mathrm{C}$. Suhu yang terukur di danau Tamblingan berada pada rentang suhu $24-25^{\circ} \mathrm{C}$ sehingga sesuai untuk kehidupan filum Chlorophyta.

Genus yang selalu ditemukan di setiap stasiun dan kepadatannya tinggi dengan jumlah tidak jauh berbeda adalah Cosmarium, Staurastum, dan Nitzschia. Menurut Sulastri (2018) Cosmarium mempunyai sebaran yang luas misalnya di perairan asam dan alkali, perairan danau dangkal, danau dalam oligotrifik dan eutrofik. Kondisi suhu yang baik untuk Cosmarium, berkisar $18-29{ }^{\circ} \mathrm{C}$ dengan $\mathrm{pH}$ 6,46-7,67. Genus tersebut mempunyai marfologi dan ukuran beragam yang mana umumnya sel terbagi menjadi dua bagian yang dikenal dengan semi-sel yang ukurannya sama. Nitzschia umum ditemukan pada perairan tawar dan laut. Menurut Choirun dkk, (2015), Nitzshia merupakan salah satu genus yang bisa menyebabkan Harmful Algal Bloom (HAB). Terjadinya Blooming apabila konsetrasi alga mencapai $10^{6} \mathrm{Sel} / \mathrm{L}$ yang dipicu oleh salah satu faktor yaitu kadar nutrient yang tinggi. Untuk genus Staurastrum, dapat ditemukan di lingkungan air tawar, laut, payau, dan pada tanah basah. Selain itu jga dapat dijumpai di tempat-tempat kering. Di periaran, genus tersebut hidup mengapung sehingga hal yang wajar jumlahnya banyak dan ditemukan disemua stasiun (Sartika dkk., 2012). Menurut Sulastri (2018), Staurastum juga biasa dijumpai di perairan miskin sampai kaya unsur hara dengan suhu 18-29 ${ }^{\circ} \mathrm{C}$. Berdasarkan penelitian Mujiyanto dkk. (2011), Staurastrum adalah penyusun utama komunitas fitoplankton pada tiap bagian kedalaman perairan sehingga dalam setiap pengamatan dapat dijumpai genus tersebut

Nilai kepadatan total rata-rata plankton Danau Tamblingan hasil pengamatan 5.757-11.197 sel/liter. Kepadatan plankton Danau Tamblingan lebih tinggi bila dibandingkan dengan danau Beratan yang berkisar 2.054-2.502 sel/liter (Ananda dkk., 2019). Berdasarkan penelitian Riyadh dkk. (2020), nilai pH danau buyan adalah 5, dimana kondisi perairan yang terlalu asam akan menyebabkan gangguan metabolisme organisme perairan khusunya plankton. Kepadatan plankton danau Tamblingan lebih rendah bila dibandingkan dengan danau Rawa Pening yang memiliki kepadatan 14.356-19.012 (Samudra dkk., 2013). Danau Rawa Pening memiliki kadar fosfat $0,10 \mathrm{mg} / \mathrm{l}$ lebih rendah dari Danau Tamblingan (Tabel 3) namun memiliki kepadatan yang lebih tinggi dari kedua danau tersebut. Dengan demikian kadar nutrient sangat berpengaruh terhadap kepadatan plankton (Rumanti dkk., 2014).

Kepadatan tertinggi Danau Tamblingan terdapat pada stasiun II dimana pada stasiun tersebut memiliki kadar nitrat dan fosfat lebih tinggi (Tabel 3) daripada stasiun I dan stasiun II. Menurut Miller (2005) stasiun II merupakan limnetic zone (lapisan terbuka), dimana pada lapisan ini permukaan air terpapar cahaya matahari yang cukup 
banyak dan pada lapisan inilah fotosintesis utama danau, dimana produser (fitoplankton) menghasilkan oksigen. Dari hal tersebut maka dapat disimpulkan bahwa perbedaan jumlah kepadatan plankton pada setiap stasiun dipengaruhi oleh faktor fisika dan kimia, terutama suhu, kecerahan, $\mathrm{pH}$ dan nutrient yang berbeda - beda.

Nilai indeks keanekaragaman plankton (Tabel 2) di ketiga stasiun adalah 1,38-1,76. Nilai itu menandakan keanekaragaman plankton di ketiga stasiun tergolong kategori sedang. Hal tersebut mengacu pada Basmi (2000) yaitu jika nilai $1 \leq H^{\prime} \leq 3$ maka keanekaragaman dianggap sedang. Nilai indeks dominansi di ketiga stasiun adalah $0,35-0,48$. Nilai tersebut menandakan tidak terdapat dominansi $(\mathrm{C} \leq 0,5)$. Nilai indeks keseragaman di ketiga stasiun berkisar antara 0,52-0,65. Odum (1971) menyatakan bahwa jika $0,75 \geq \mathrm{E} \geq 0,5$ maka keseragaman jenis tergolong sedang atau komunitas tergolong labil.

\section{Aktivitas masyarakat sekitar Danau Tamblingan}

Hasil wawancara dengan masyarakat yang berprofesi sebagai petani sekitar di Danau Tamblingan (Tabel 3), bahwa dari kedelapan responden hanya dua orang yang memiliki luas lahan 10 are, tiga orang dengan luas lahan 20 are, satu orang dengan luas lahan 40 are, satu orang dengan luas lahan 50 are, dan satu orang dengan luas lahan 70 are. Dari delapan responden lima orang menanam tanaman pecah seribu, dua orang menanam cengkeh, dan satu orang yang menanam kopi. Para petani sebagian besar menggunakan pupuk organik dalam memupuk tanaman dengan intesitas penggunaan yang paling sering adalah tiga kali dalam setahun. Hal tersebut disebabkan karena tanaman yang banyak ditanam adalah tanaman tahunan diantaranya bunga pecah seribu, kopi, dan cengkeh. Dalam penggunaan pestisida oleh petani hanya $25 \%$ dengan intesitas penggunaan 1-24 kali dalam setahun dan $75 \%$ tidak menggunakan sama sekali. Intensitas penggunaan pestisida paling sering adalah 24 kali dalam setahun.

Aktivitas masyarakat pada badan Danau Tamblingan adalah sebagai nelayan (Tabel 4). Sebagian besar mereka menagkap ikan menggunakan kail dan jaring yang dipasang di tengah danau. Ikan yang paling banyak diperoleh adalah ikan mujair dengan peruntukkan dijual ataupun dikonsumsi tergantung dari jumlah yang diperoleh. Selanjutnya adalah ikan lele dimana menurut Santoso (1995) ikan tersebut mampu hidup di perairan yang aliran airnya tidak terlalu deras misalnya di sungai, danau, dan waduk. Selanjutnya adalah ikan zebra yang mempunyai ukuran kurang lebih dari $10 \mathrm{~cm}$. Ciri khas ikan zebra adalah pada tubuhnya terdapat garisgaris vertical berwarna hitam. Ikan zebra sering ditemukan pada bagian tepi danau, ikan tersebut menyukai daerah yang berbatu dan banyak tanaman tanaman air (Yamamoto and Tagawa. 2000). Pada badan perairan Danau Tamblingan hanya diperuntukkan untuk menangkap ikan dan wisata air menggunakan parahu kayu yang telah disediakan.

\section{SIMPULAN}

Struktur komunitas plankton Danau Tamblingan terdiri atas lima filum (Chrysophyta, Chlorophyta, Cyanophyta, Protozoa, Arthropoda) dan 27 genus. Genus yang paling banyak ditemukan adalah Cosmarium, Staurastum, dan Nitzschia. Nilai rata-rata kepadatan 
plankton perairan Danau Tamblingan adalah9381 sel/Liter dengan lideks keanekaragaman tergolong sedang $(\mathrm{H}=$ 1,56), dengan sebaran jumlah antar jenis tergolong seragam $(\mathrm{E}=0,51)$ dan tidak ada dominansi $(\mathrm{C}=0,49)$

Aktivitas masyarakat pada kawasan Danau Tamblingan adalah sebagai petani dan nelayan dan dianggap ramah terhadap ekosistem serta tidak berdampak terhadap danau. Aktivitas pertanian mengutamakan penggunaan pupuk organik (60 \%), penggunaan pestisida yang rendah $(25 \%)$ dan menangkap ikan dengan kail dan jaring.

\section{DAFTAR PUSTAKA}

Ananda, Y., I. W. Restu, dan R. Ekawati. 2019. Status Tropik dan Struktur Komunitas Fitoplankton di Danau Beratan, Desa Candikuning, Kecamatan Baturiti, Kabupaten Tabanan, Provinsi Bali. Jurnal Metamorfosa. 6(1): 58 - 66 .

Barus, T. A. 2004. Pengantar Limnologi Studi Tentang Ekosistem Air Daratan. USU press. Medan.

Basmi, H. J. 2000. Planktonologi: Plankton Sebagai Indikator Kualitas Perairan. Fakultas Perikanan dan Ilmu Kelautan, Institut Pertanian Bogor. Bogor.

Belcher, H. and E. Swale. 1978. A Beginner's Guide of Freshwater Algae. Cambridge. London.

Choirun, A., S.H.J. Sari dan F. Iranawati. 2015. Identifikasi Fitoplankton Spesies HAB Saat Kondiis Pasang di Perairan Pesisir Brondong, Lamongan, Jawa Timur. Jurnal Ilmu Kelautan Dan Perikanan. 25(2): 56-66.

Effendi, H. 2003. Telaah Kualitas Air Bagi Pengelolan Sumber Daya dan Lingkungan Perairan. Kanisius. Yogyakarta.
Fauziah, S. M. dan , A. N. Laily. 2015. Identifikasi Mikroalga dari Divisi Chlorophyta di Waduk Sumber Air Jaya Dusun Krebet Kecamatan Bululawang Kabupaten Malang. Journal Bioedukasi. 8(1): 20-22.

Fukuyo, Y., \& V. M. Borja. 2000. Marine dinoflagellates in the Philippines. Asian Natural Science Centre, Tokyo

Kep.MENLH. 2004. Keputusan Kantor Menteri Negara Lingkungan Hidup No. Kep 51 / MENLH/I/2004. Tentang Pedoman Penetapan Baku Mutu Lingkungan. hal 11.

Krebs, C.J. 1989. Ecological Methodology. Harper Collins Publisher. New York

Manuaba, I. B. P. 2009. Cemaran Pestisida Karbamat dalam Air Danau Buyan Buleleng Bali. Jurnal Kimia. 3(1): $47-54$.

Miller Jr, G. T. 2005. Essential of Ecology. Thomson Brooks/cole. United States.

Mujiyanto, D. E. H., Thajhjo dan Y. Sugianti. 2011. Hubungan antara Kelimpahan Fitoplankton dengan Konsentrasi N:P di Waduk Ir. H. Djuanda, Jawa Barat. Jurnal Limnotek. 18 (18): 15-25.

Munthe, Y. V., R. Aryawati, dan Isnaini. 2012. Struktur komunitas dan sebaran Fitoplankton di Perairan Sungsang Sumatera Selatan. Maspari jurnal. 4(1): 122 - 130.

Odum, E.P., 1971, Fundamental of Ecology. W.B. Sounders Company, Philadelphia.

Pratiwi, N. T. M., E. M. Adiwilaga, J. Basmi, M. Krisanti, O. Hadijah, dan P. K. Wulandari. 2007. Status Limnologi Situ Cilala Mengacu pada Kondisi Parameter Fisika, Kimia dan Biologi Perairan. Jurnal Perikanan. 9(1) : 82-94.

Risamasu, F. J.L, dan H. B. Prayitno. 2011. Kajian Zat Hara Fosfat, Nitrit, Nitrat dan Silikat di Perairan 
Kepulauan Matasiri, Kalimantan

Selatan. Pusat Penelitian

Oseanografi-LIPI. 16(3): 135-142.

Riyadh, Wesnawa, I. G. A., dan Citra, I. P.

A. 2020. Dampak Potensi

Pariwisata Terhadap Kualiatas Air

Danau Beratan. Jurnal Pendidikan

Geografi Undiksha. 8(1): 23 - 32.

Rumanti, M., S. Rudiyanti, dan M. N.

Suparjo. 2014. Hubungan Antara

Kandungan Nitrat dan Fosfat

Dengan Kelimpahan Fitoplankton

di Sungai Bremi Kabupaten

Pekalongan. Jurnal Maquares. 3(1): $168-176$.

Sachlan, M. 1982. Planktonologi. Fakultas Peternakan dan Perikanan Universitas Diponegoro. Semarang.

Samudra, S. R., T. R. Soeprobowati, dan M. Izzati. 2013. Komposisi, Keelimpahan dan Keanekaragaman Fitoplankton Danau Rawa Pening Kabupaten Semarang. Jurnal Bioma. 15(1): 6 - 13.

Santoso, B. 1995. Petunjuk Praktis Budidaya Ikan Lele Dumbo dan Lokal. Kanisius. Yogyakrta.

Sartika, D., N.E. Fajri., dan A.H. Sinamarta. 2012. Keanekaragaman Fitoplankton dan Hubungannya dengan Nitrat dan Fosfat di Danau Singkarak Kabupaten Solok Provinsi Sumatera Barat. Universitas Riau.

Shirota, A., 1966. Plankton of south Vietnam, Overseas Tecnical Co. Agency, Japan

Soliha, E. S. Y., S, Rahayu, dan Triastinurmiatiningsih. 2008. Kualitas Air dan Keanekaragaman Plankton di Danau Cikaret, Cibinong, Bogor. Jurnal Ekologia. 16(2): $1-10$

Sulastri. 2018. Fitoplankton Danau-Danau di Pulau Jawa: Keanekaragaman dan Perannya Sebagai Bioindikator. LIPI Press. Jakarta.

Supono. 2008. Analisis Diatom Epipelic Sebagai Indikator Kualitas
Lingkungan Tambak Untuk Budidaya Udang. Program Pasca Sarjana Universitas Diponegoro. (Thesis). Tidak dipublikasikan.

Sutomo. 2014. Ekslporasi Keberadaan Tumbuhan Langka Lokal Bali di Kawasan Hutan Danau BuyanDanau Tamblingan dan Beberapa Desa di Kabupaten Buleleng Bali. Jurnal Al-Ahzar Indonesia Seri Sains dan Teknologi. 2(4): 253 259.

Wibowo, A. 2017. Statistic Penggunaan Lahan Kabupaten Buleleng 2017. BPS Kabupaten Buleleng. Buleleng.

Yamamoto, M.N. and A. W. Tagawa . 2000. Hawai'I's Native and Exotic Freshwater Animals. Mutual Publishing, Honolulu. 